\title{
Interactive Effects of Zinc and Zilpaterol Hydrochloride on Bovine $\beta$-Adrenergic Receptors
}

\author{
J. E. Hergenreder ${ }^{1}$, T. L. Harris ${ }^{1}$, J. O. Baggerman'1, A. D. Hosford ${ }^{1}$, M. Branine ${ }^{2}$, B. J. Johnson ${ }^{*}$ \\ ${ }^{1}$ Department of Animal and Food Sciences, Texas Tech University, Lubbock, TX, USA \\ ${ }^{2}$ Zinpro Corporation, Eden Prairie, MN, USA \\ Email: *bradley.johnson@ttu.edu
}

How to cite this paper: Hergenreder, J.E., Harris, T.L., Baggerman, J.O., Hosford, A.D., Branine, M. and Johnson, B.J. (2020) Interactive Effects of Zinc and Zilpaterol Hydrochloride on Bovine $\beta$-Adrenergic Receptors. Open Journal of Animal Sciences, 10, 402-413.

https://doi.org/10.4236/ojas.2020.103025

Received: April 17, 2020

Accepted: June 15, 2020

Published: June 18, 2020

Copyright $\odot 2020$ by author(s) and Scientific Research Publishing Inc. This work is licensed under the Creative Commons Attribution International License (CC BY 4.0).

http://creativecommons.org/licenses/by/4.0/ Open Access

\begin{abstract}
The objective of this study was to determine if the addition of zinc $(\mathrm{Zn})$ in combination with zilpaterol $\mathrm{HCL}(\mathrm{ZH})$ affected the interaction of $\mathrm{ZH}$ with the beta ${ }_{2}$-adrenergic receptor $(\beta$-AR) by altering cAMP production, gene expression, and protein abundance in cultured skeletal muscle cells. Cultures of muscle bovine satellite cells were established and treated at $120 \mathrm{~h}$ with: 1) 0

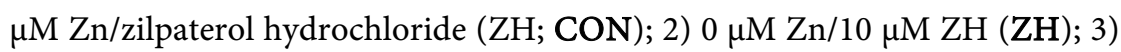
$1 \mu \mathrm{M} \mathrm{Zn}$ from $\mathrm{Zn}$ chloride/0 $\mu \mathrm{M} \mathrm{ZH}(\mathrm{Zn}) ; 4) 1 \mu \mathrm{M} \mathrm{Zn}$ from $\mathrm{Zn}$ chloride/10 $\mu \mathrm{M} \mathrm{ZH}(\mathrm{ZN} / \mathrm{ZH})$ in differentiation media for an additional 0, 6, 24, 48 and 96 h. Protein and mRNA were isolated and quantified at 24 and $96 \mathrm{~h}$, and cAMP was measured at $0,6,24,48$ and $96 \mathrm{~h}$. At $0,24,48$ and $96 \mathrm{~h}$, no differences $(P>0.05)$ were detected in cAMP production. At $6 \mathrm{~h}, \mathrm{Zn}$ cells had the greatest concentration of cAMP $(P<0.05)$ compared to $\mathrm{ZH}$ treatments. No differences $(P>0.05)$ were detected in mRNA abundance at $24 \mathrm{~h}$. At $96 \mathrm{~h}, 0 \mu \mathrm{M}$ $\mathrm{Zn} / 10 \mu \mathrm{M} \mathrm{ZH}$ cells had an increased abundance of myosin heavy chain (MHC)-I mRNA $(P<0.05)$ compared to CON. Furthermore, ZH had a greater abundance of MHC-IIX mRNA $(P<0.05)$ and a tendency for a greater abundance of IGF-1 mRNA $(P<0.15)$ compared to CON and ZN/ZH. No differences $(P>0.05)$ were detected in the protein abundance of $\beta 1 \mathrm{AR}$ and the $\beta 2 \mathrm{AR}$. These results indicated $\mathrm{Zn}$ and $\mathrm{ZH}$ in combination did not have an additive effect on $\beta_{2}$-AR function as indicated by cAMP concentrations.
\end{abstract}

\section{Keywords}

$\beta$-Adrenergic Receptor, Zilpaterol Hydrochloride, Zinc

\section{Introduction}

Beta-adrenergic agonists ( $\beta$-AA) are commonly used in the beef cattle feedlot 
industry to improve growth performance and carcass characteristics through increased protein synthesis and decreased protein degradation [1]. Beta-adrenergic agonists have also been reported to increase lipolysis and decrease lipogenesis in adipose tissue [1] [2] [3]. These $\beta$-AA work through an interaction with the beta-adrenergic receptors ( $\beta$-AR) [4] [5]. Zilpaterol $\mathrm{HCl}(\mathrm{ZH})$, a $\beta$-AA used in cattle, primarily binds with the $\beta_{2}$-AR, which is the most predominant $\beta$-AR found in cattle muscle and adipose tissue [1] [2]. Via a secondary messenger signal cascade event, cyclic adenosine monophosphate (cAMP) is activated thereby resulting in protein accretion and lipid catabolism [1] [2] [3].

Overstimulation of the $\beta$-ARs by $\beta$-AA has been reported to result in receptor desensitization [6] [7]. Receptor desensitization results in a down regulation of adenylate cyclase catalytic activity resulting in a reduction of cAMP synthesis [8]. When the $\beta$-ARs become desensitized, they are sequestered within an intracellular vesicle, thus losing the ability to induce signal transduction [6] [7].

Research has shown that the $\beta_{2}$-AR potentially have multiple allosteric binding sites for zinc ( $\mathrm{Zn})$ [1] [9]. Swaminath, Lee and Kobilka [10], suggested there are two main binding sites for $\mathrm{Zn}$ on the $\beta$-AR; one affects the agonist's ability to bind to the receptor, while the other affects the antagonist's ability to bind to the receptor thus increasing cAMP production. Zinc also regulates adenylate cyclase (AC) and cyclic nucleotide phosphodiesterase (PDE) which are involved in the synthesis and degradation of cAMP after the $\beta$-AR is activated [11]. Several studies have reported that the catalytic activity of $\mathrm{AC}$ is inhibited by $\mathrm{Zn}$; however, the mechanism responsible for this phenomenon is still unknown [12] [13] [14]. von Bülow, Rink and Haase [15] reported the addition of $\mathrm{Zn}$ to cellular lysate inhibits cyclic nucleotide degradation, signifying increases in cellular $\mathrm{Zn}$ will block PDE activity.

Little is known about how the combination of $\mathrm{ZH}$ and $\mathrm{Zn}$ might influence the $\beta$-AR's ability to produce cAMP, and its regulation of mRNA and protein synthesis. Thus, the objective of the present research was to determine if utilizing $\mathrm{Zn}$ in combination with $\mathrm{ZH}$ would affect the downstream signal transduction of cascade events commonly associated with $\beta$-AA thus altering cAMP activation, and mRNA and protein abundance.

\section{Materials and Methods}

\subsection{Experimental Design and Treatments}

This experiment was conducted as a $2 \times 2$ factorial, and each replicate $(n=4)$ was plated and cultured simultaneously. These experiments were conducted in 2017 in the Department of Animal and Food Sciences at Texas Tech University. The cells were treated with a laboratory grade $\mathrm{Zn}$ chloride (Acros Organics, Fisher Scientific, Fair Lawn, NJ), ZH, or a combination of the two. Each well was

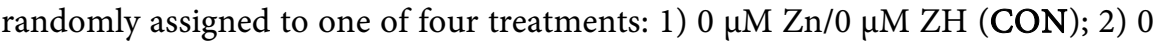
$\mu \mathrm{M} \mathrm{Zn} / 10 \mu \mathrm{M} \mathrm{ZH}(\mathrm{ZH})$; 3) $1 \mu \mathrm{M} \mathrm{Zn/0} \mu \mathrm{M} \mathrm{ZH}(\mathrm{Zn})$; 4) $1 \mu \mathrm{M} \mathrm{Zn} / 10 \mu \mathrm{M} \mathrm{ZH}$ $(\mathrm{ZN} / \mathrm{ZH})$. 


\subsection{Satellite Cell Isolation}

Satellite cell isolation was performed following procedures outlined by Johnson et al. [6]. Muscle tissue samples were extracted from the semimembranosus muscle of market age cattle at harvest. Tissue was then subjected to satellite cell extraction procedures, to isolate satellite cells from muscle tissue. Under a sterile hood, adipose and connective tissue were removed from muscle. The muscle was ground through a sterile grinder sterilized in $70 \%$ ethanol for $24 \mathrm{~h}$ prior to use. Ground muscle was then incubated in a solution consisting of $0.1 \%$ pronase (Calbiochem, La Jolla, CA) and Earl's Balanced Salt Solution (EBSS; Sigma, St. Louis, $\mathrm{MO}$ ) for $1 \mathrm{~h}$ at $37^{\circ} \mathrm{C}$. At $10 \mathrm{~min}$ intervals, the samples were shaken vigorously. Following incubation, differential centrifugation at $1500 \times g$ for $4 \mathrm{~min}$ at $25^{\circ} \mathrm{C}$ was performed on the sample. The resulting supernatant was removed, and the pellet suspended in phosphate buffered saline (PBS; Invitrogen, Grand Island, NY; $140 \mathrm{mM} \mathrm{NaCl}, 3 \mathrm{mM} \mathrm{Na} 2-\mathrm{H}-\mathrm{PO}_{4}$ ). The resulting pellet was then centrifuged at $500 \times g$ for $10 \mathrm{~min}$ at $25^{\circ} \mathrm{C}$. The supernatant was transferred into another container and centrifuged at $15,000 \times g$ for $10 \mathrm{~min}$ at $25^{\circ} \mathrm{C}$ to form a pellet consisting of mononucleated cells. The differential centrifugation and the PBS wash steps were repeated twice. Total mononucleated cells were then suspended in cold Dulbecco's Modified Eagle Medium (DMEM; Invitrogen, Grand Island, NY) containing 10\% fetal bovine serum (FBS; Invitrogen) and 10\% dimethylsulfoxide (DMSO; Sigma). The cell solution was then aliquoted into 1.8 $\mathrm{mL}$ nunc cryo tube vials (Fisher Scientific). Cells were then placed in a $-80^{\circ} \mathrm{C}$ freezer for $24 \mathrm{~h}$ and stored in liquid nitrogen until needed.

\subsection{Satellite Cell Culture}

Bovine satellite cells were cultured in 6-well plates (RNA and Protein analysis) or 24-well plates (cAMP analysis). Plates were coated with reduced factor matrigel (Matrigel; BD Biosciences, Bedford, MA) at least $1 \mathrm{~h}$ prior to plating cells and kept at $37^{\circ} \mathrm{C}$. Cells were plated and placed in a $37^{\circ} \mathrm{C}$ incubator for $24 \mathrm{~h}$ in $10 \%$ Fetal Bovine Serum (FBS; GIBCO ${ }^{\circledR}$; Invitrogen)/DMEM-3X antibiotic antimycotic (Invitrogen) 0.3X gentamycin (Sigma) media. Cells were rinsed and allowed to proliferate for $120 \mathrm{~h}$ in $10 \%$ FBS/DMEM-3X antibiotic antimycotic $0.3 \mathrm{X}$ gentamycin at $37^{\circ} \mathrm{C}$. At $120 \mathrm{~h}$ media was changed from proliferation to differentiation media (3\% Horse Serum; GIBCO ${ }^{\circledR}$; Invitrogen)/DMEM-3X antibiotic antimycotic $0.3 \mathrm{X}$ gentamycin). The treatment substrates were added to the differentiation media. Cells that were designated for mRNA and protein quantification were treated and incubated for either 24 or $96 \mathrm{~h}$ in differentiation media, while cells destined for cAMP analysis were treated and incubated for a total of $0,6,24,48$, or $96 \mathrm{~h}$ in differentiation media.

\subsection{RNA Isolation and Real-Time Quantitative Reverse Transcription Polymerase Chain Reaction}

At 24 or $96 \mathrm{~h}$ of treatment, cells from 6-well plates were harvested for mRNA 
analysis. The cells were rinsed 3 times in PBS, and total mRNA isolated with ice-cold buffer containing TRI Reagent ${ }^{\circledR}$ (Sigma, St. Louis, MO). Approximately $200 \mathrm{~mL}$ of TRI Reagent ${ }^{\circledR}$ were added to each well, and then incubated for $5 \mathrm{~min}$ at $25^{\circ} \mathrm{C}$. The wells were then scraped to ensure release of all cells from the bottom of the well. Homogenate was pipetted into a microcentrifuge tube, $100 \mu \mathrm{L}$ of chloroform were added, vortexed for $30 \mathrm{~s}$ and incubated for $5 \mathrm{~min}$ at $25^{\circ} \mathrm{C}$. The sample was then centrifuged at $15,000 \times g$ for $15 \mathrm{~min}$ that causing the samples to separate into 3 layers. The top supernatant layer was pipetted off and placed into a new microcentrifuge tube. Ice cold isopropyl alcohol $(250 \mu \mathrm{L})$ was added to the supernatant, shaken, and incubated for $10 \mathrm{~min}$ at $25^{\circ} \mathrm{C}$. Samples were centrifuged at $15,000 \times g$ for $10 \mathrm{~min}$. The supernatant was poured off, the RNA pellet at the bottom of each tube air dried, and $500 \mu \mathrm{L}$ of $75 \%$ ethanol was added to each tube to rinse and suspend the RNA pellet. Samples were then placed in a $-80^{\circ} \mathrm{C}$ freezer until needed (no longer than 3 months). Samples were removed from the freezer and thawed on ice and centrifuged at $250 \times g$ for $10 \mathrm{~min}$, ethanol poured off, and the pellet air dried. Nuclease free water $(30 \mu \mathrm{L})$ was added to dissolve the RNA pellet. The concentration of RNA was determined with a spectrophotometer at an absorbance of $260 \mathrm{~nm}$ using a NanoDrop 1000 (NanoDrop products, Wilmington, DE). Samples were treated with DNAse to remove any DNA contaminants using a DNA-free kit (Life Technologies). The RNA was then subjected to reverse-transcription to produce cDNA. The resulting CDNA was used for real-time quantitative reverse transcription-PCR (RT-qPCR) to measure the abundance of AMP-activated protein kinase alpha (AMPK $\alpha$ ), beta-1 adrenergic receptor $(\beta 1 \mathrm{AR})$, beta- 2 adrenergic receptor ( $\beta 2 \mathrm{AR})$, insulin-like growth factor-I (IGF-I), myosin heavy chain (MHC)-I, MHC-IIA, MHC-IIX, C-enhancer binding protein beta (CEBP $\beta$ ), G-protein coupled receptor 43 (GPR43), peroxisome proliferator-activated receptor gamma (PPAR $\gamma$ ), and stearoyl-CoA desaturase (SCD) mRNA relative to the abundance of ribosomal protein subunit 9 (RPS9) mRNA in total RNA isolated from cells. Bovine primers and probes for AMPK $\alpha, \beta 1 \mathrm{AR}, \beta 2 \mathrm{AR}$, IGF-I, MHC-I, MHC-IIA, MHC-IIX, GPR43, SCD, CEBP $\beta$, and PPAR $\gamma$ are presented in Table 1 . Assays were performed in the GeneAmp 7900HT Sequence Detection System (Applied Biosystems, Life Technologies) using thermal cycling parameters recommended by the manufacturer ( 40 cycles of $15 \mathrm{~s}$ at $95^{\circ} \mathrm{C}$ and $1 \mathrm{~min}$ at $60^{\circ} \mathrm{C}$ ).

\subsection{Protein Extraction and Western Blots}

At 24 or $96 \mathrm{~h}$ of treatment, cells from 6-well plates were harvested for protein analysis. The cells were rinsed 3 times with PBS. Protein from cells was isolated with ice-cold buffer containing mammalian protein extraction reagent (M-PER; Fisher Scientific, Fair Lawn, NJ), protein inhibitor (Roche, Branchburg, NJ), and $2 \mathrm{mM} \mathrm{Na}_{3} \mathrm{VO}_{4}$ (Fisher Scientific). Approximately $500 \mu \mathrm{L}$ of M-PER was added to each well and incubated for $5 \mathrm{~min}$ at $25^{\circ} \mathrm{C}$ while shaking. The wells were then scraped to ensure all cells were released from the bottom of the well. Samples 
Table 1. Sequence of bovine-specific PCR primers and TaqMan probes to be used for determination of expression of mRNA of AMPK $\alpha$, MHC-I, MHC-IIA, MHC-IIX, IGF-I, $\beta 1 \mathrm{AR}, \beta 2 \mathrm{AR}, \beta 3 \mathrm{AR}, \mathrm{CEBP} \beta$, GPR43, GPR41, Glut 4 , PPAR $\gamma$, SCD and RPS9*.

\begin{tabular}{|c|c|}
\hline Primer & Sequence ( $5^{\prime}$ to $\left.3^{\prime}\right)$ \\
\hline \multicolumn{2}{|c|}{ AMPk $\alpha$ (accession \#NM_001109802) } \\
\hline Forward & ACCATTCTTGGTTGCTGAAACTC \\
\hline Reverse & CACCTTGGTGTTTGGATTTCTG \\
\hline TaqMan probe & 6FAM-CAGGGCGCGCCATACCCTTG-TAMRA \\
\hline \multicolumn{2}{|c|}{ MHC-I (accession \#AB059400) } \\
\hline Forward & СССАСТТСТСССТGАТССАСТАС \\
\hline Reverse & TTGAGCGGGTCTTTGTTTTTCT \\
\hline TaqMan probe & 6FAM-CCGGCACGGTGGACTACAACATCATAG-TAMRA \\
\hline \multicolumn{2}{|c|}{ MHC-IIA (accession \#AB059398) } \\
\hline Forward & GCAATGTGGAAACGATCTCTAAAGC \\
\hline Reverse & GCTGCTGCTCCTCCTCCTG \\
\hline TaqMan probe & 6FAM-TCTGGAGGACCAAGTGAACGAGCTGA-TAMRA \\
\hline \multicolumn{2}{|c|}{ MHC-IIX (accession \#AB059399) } \\
\hline Forward & GGCCСАСТTCTCССТСАTTC \\
\hline Reverse & CCGACCACCGTCTCATTCA \\
\hline TaqMan probe & 6FAM-CGGGCACTGTGGACTACAACATTACT-TAMRA \\
\hline \multicolumn{2}{|c|}{ IGF-I (accession \#X15726) } \\
\hline Forward & TGTGATTTCTTGAAGCAGGTGAA \\
\hline Reverse & AGCACAGGGCCAGATAGAAGAG \\
\hline TaqMan probe & 6FAM-GCCCATCACATCCTCCTCGCA-TAMRA \\
\hline \multicolumn{2}{|c|}{$\beta 1 \mathrm{AR}$ (accession \#AF188187) } \\
\hline Forward & GTGGGACCGCTGGGAGTAT \\
\hline Reverse & TGACACACAGGGTCTCAATGC \\
\hline TaqMan probe & 6FAM-CTCCTTCTTCTGCGAGCTCTGGACCTC-TAMRA \\
\hline \multicolumn{2}{|c|}{$\beta 2 \mathrm{AR}$ (accession \#NM_174231) } \\
\hline Forward & CAGCTCCAGAAGATCGACAAATC \\
\hline Reverse & CTGCTCCACTTGACTGACGTTT \\
\hline TaqMan probe & 6FAM-AGGGCCGCTTCCATGCCC-TAMRA \\
\hline \multicolumn{2}{|c|}{ CEBP $\beta$ (accession \#NM_176788) } \\
\hline Forward & CCAGAAGAAGGTGGAGCAACTG \\
\hline Reverse & TCGGGCAGCGTCTTGAAC \\
\hline TaqMan probe & 6FAM-CGCGAGGTCAGCACCCTGC-TAMRA \\
\hline \multicolumn{2}{|c|}{ GPR43 (accession \#FJ562212) } \\
\hline Forward & GGCTTTCCCCGTGCAGTA \\
\hline Reverse & ATCAGAGCAGCCATCACTCCAT \\
\hline
\end{tabular}




\begin{tabular}{ll} 
Continued & \\
\hline TaqMan probe & 6FAM-AAGCTGTCCCGCCGGCCC-TAMRA \\
PPAR $\gamma$ (accession \#NM_181024) & \\
Forward & ATCTGCTGCAAGCCTTGGA \\
Reverse & TGGAGCAGCTTGGCAAAGA \\
TaqMan probe & 6FAM-CTGAACCACCCCGAGTCCTCCCAG-TAMRA \\
SCD (accession \#AB075020) & \\
Forward & TGCCCACCACAAGTTTTCAG \\
Reverse & GCCAACCCACGTGAGAGAAG \\
TaqMan probe & 6FAM-CCGACCCCCACAATTCCCG-TAMRA \\
RPS9 (accession \#DT860044) & \\
Forward & GAGCTGGGTTTGTCGCAAAA \\
Reverse & GGTCGAGGCGGGACTTCT \\
TaqMan probe & 6FAM-ATGTGACCCCGCGGAGACCCTTC-TAMRA \\
\hline
\end{tabular}

${ }^{*} \mathrm{AMPK} \alpha=$ AMP-activated protein kinase alpha, MHC-I $=$ myosin heavy chain-I, MHC-IIA $=$ myosin heavy chain-IIA, MHC-IIX = myosin heavy chain-IIX, $\beta 1 \mathrm{AR}=$ beta 1 adrenergic receptor, $\beta 2 \mathrm{AR}=$ beta 2 adrenergic receptor, $\beta 3 \mathrm{AR}=$ beta 3 adrenergic receptor, $\mathrm{CEBP} \beta=\mathrm{C}$-enhancer binding protein beta, GPR 43 $=$ G-protein coupled receptor 43 , GPR41 $=$ G-protein coupled receptor 41 , Glut $4=$ glucose transporter type $4, \operatorname{PPAR} \gamma=$ peroxisome proliferator-activated receptor gamma, $\mathrm{SCD}=$ stearoyl-CoA desaturase and RPS9 $=$ ribosomal protein $S 9$.

were centrifuged at $1500 \times g$ for $15 \mathrm{~min}$., separating the sample into 3 layers. The middle supernatant layer was removed and placed into a microcentrifuge tube. Protein samples were then diluted with either M-PER to determine protein concentration using the Pierce ${ }^{\mathrm{TM}} \mathrm{BCA}^{\mathrm{TM}}$ protein assay (Thermo Fisher Scientific, Fairlawn, NJ). Protein concentration was then determined using a NanoDrop 1000 spectrophotometer (Thermo Scientific, Wilmington, DE) at $562 \mathrm{~nm}$. All samples were then diluted to the same concentration. Modified Wangs tracking dye was added to samples for western blot analysis. Samples were denatured with $\beta$-mercaptoethanol and incubated for $2 \mathrm{~min}$ at $95^{\circ} \mathrm{C}$. Samples were then loaded onto Novex $4 \%$ - 12\% Bis-Tris gels (Invitrogen), and protein was separated by gel electrophoresis run for approximately $35 \mathrm{~min}$ at $165 \mathrm{~V}$ and $27 \mathrm{~mA}$. Proteins were transferred onto a nitrocellulose membrane (Invitrogen) for 7 min. Following transfer, the membrane were incubated with non-fat dry milk (BIO RAD, Hercules, CA), $10 \% 10 \times$ Tris-buffered saline (TBS) in NanoPure water for $1 \mathrm{~h}$ at $25^{\circ} \mathrm{C}$ to block non-specific antibody binding. The blocking solution was then removed from the membrane. The appropriate primary antibody: 1:1000 $\alpha$-beta $1 \mathrm{AR}$, rabbit, IgG (abcam ${ }^{\circledR}$, Cambridge, MA); 1:1000 $\alpha$-beta $2 \mathrm{AR}$, goat, IgG (abcam) was mixed into $1 \times$ TBS-Tween solution, added to the membrane and allowed to incubate for $2 \mathrm{~h}(\beta 1 \mathrm{AR})$ or $1 \mathrm{~h}(\beta 2 \mathrm{AR})$ at $25^{\circ} \mathrm{C}$. The membrane was then rinsed 3 times for $10 \mathrm{~min}$ in TBS-Tween. The appropriate Alexa fluorescent antibodies: goat $\alpha$-rabbit, IgG, Alexa-Fluor 633 (Invitrogen); donkey $\alpha$-goat, IgG, Alexa-Fluor 633 (Invitrogen) were then added at a dilution of 
1:2000 in TBS-Tween to the membrane and incubated for $1 \mathrm{~h}$ at $25^{\circ} \mathrm{C}$ in the absence of light. The membranes were then rinsed 3 times for $10 \mathrm{~min}$ in TBS-Tween in unlighted conditions. The membranes were then dried and visualized using Imager Scanner II and ImageQuant TL software. Densitometry measurements were made on the bands corresponding to $\beta 1 \mathrm{AR}$ and $\beta 2 \mathrm{AR}$ using a molecular weight standard for reference (Precision Plus Protein ${ }^{\mathrm{TM}}$ All Blue Standards; BIO RAD).

\section{6. cAMP Isolation and ELISA}

After $0,6,24,48$, and $96 \mathrm{~h}$, cells from 24-well plates were harvested for cAMP analysis. Cells were rinsed 3 times in PBS. Then $100 \mu \mathrm{L}$ of $0.1 \mathrm{M} \mathrm{HCl}$ was used to lyse the cells. Cells were incubated for $5 \mathrm{~min}$ at $25^{\circ} \mathrm{C}$ while shaking. The wells were then scraped to ensure all cells were lysed and released from the bottom of the well. The sample was taken from the wells and placed into microcentrifuge tubes. An enzyme-linked immunosorbent assay (ELISA; Sigma, St. Louis, MO) was performed on samples to determine cAMP concentration, following instructions provided by the manufacturer. The results were read with a Spectra max 380 pc plate reader and Softmax Pro software.

\subsection{Statistical Analysis}

Data were analyzed using the GLIMMIX procedure of SAS (v.9.3, SAS Institute; Carey, NC). The model included treatment as the fixed effect, and the Kenward-Roger adjustment was used to correct degrees of freedom. Means were separated using the LSMEANS procedure PDIFF option and considered different when $P \leq 0.05$. Tendencies for differences among treatment means were declared when $0.05<P \leq 0.15$.

\section{Results and Discussion}

At $0,6,24,48$, and $96 \mathrm{~h}$ of incubation, cAMP was measured with no difference observed between treatments at $0,24,48$, and $96 \mathrm{~h}(P>0.05$; Table 2$)$. However,

Table 2. Relative cAMP concentration ${ }^{1}$ changes in bovine skeletal muscle satellite cells treated with zinc $(\mathrm{Zn})$ and zilpaterol hydrochloride $(\mathrm{ZH})$.

\begin{tabular}{ccccccc}
\hline \multicolumn{7}{c}{ Treatment $^{2}$} \\
\hline Hour & Control & $\mathrm{ZH}$ & $\mathrm{Zn}$ & $\mathrm{Zn} / \mathrm{ZH}$ & SEM $^{3}$ & $P$-Value \\
\hline 0 & 0.228 & 0.233 & 0.225 & 0.225 & 0.009 & 0.857 \\
06 & $0.336^{\mathrm{ab}}$ & $0.322^{\mathrm{b}}$ & $0.354^{\mathrm{a}}$ & $0.327^{\mathrm{b}}$ & 0.010 & 0.028 \\
24 & 0.265 & 0.241 & 0.266 & 0.248 & 0.014 & 0.231 \\
48 & 0.211 & 0.201 & 0.203 & 0.198 & 0.009 & 0.590 \\
96 & 0.202 & 0.198 & 0.206 & 0.204 & 0.014 & 0.955 \\
\hline
\end{tabular}

a,b Means in the same row having different superscripts are significant at $P=0.05$. ${ }^{1} \mathrm{Picomoles}$ of $\mathrm{cAMP} / \mathrm{ml}$. ${ }^{2} \mathrm{Control}=0 \mu \mathrm{M} \mathrm{ZH} / 0 \mu \mathrm{M} \mathrm{Zn}$ chloride, $\mathrm{ZH}=10 \mu \mathrm{M} \mathrm{ZH} / 0 \mu \mathrm{M} \mathrm{Zn}$ chloride, $\mathrm{Zn}=0 \mu \mathrm{M} \mathrm{ZH} / 1 \mu \mathrm{M} \mathrm{Zn}$ chloride, $\mathrm{Zn} / \mathrm{ZH}=1 \mu \mathrm{M} \mathrm{Zn}$ chloride $/ 10 \mu \mathrm{M} \mathrm{ZH}$. ${ }^{3}$ Pooled standard error of the mean. 
at $6 \mathrm{~h}$, the $\mathrm{ZN}$ cells had a greater concentration of cAMP compared to $\mathrm{ZH}$ treatments $(P<0.05$; Table 2$)$. This is in contrast to that reported by [16], who reported no difference in cAMP concentration at $6 \mathrm{~h}$ between bovine satellite cells treated with $\mathrm{Zn}$ and ractopamine $\mathrm{HCl}(\mathrm{RH})$. In the Harris [16] study, using $\mathrm{Zn}$

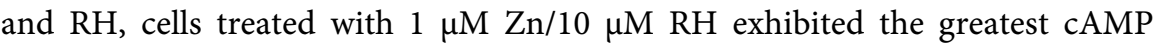
concentration at $24 \mathrm{~h}$ and by $96 \mathrm{~h}$ the control group had a greater concentration of cAMP compared to the cells treated with RH only [16]. Ractopamine $\mathrm{HCl}$ is $\beta$-AA used in beef and pork production that primarily binds to $\beta 1 \mathrm{AR}$ [17]. Ractopamine $\mathrm{HCl}$ does not affect bovine cells to the extent as $\mathrm{ZH}$ because the majority of the $\beta$-AR are $\beta 2 \mathrm{AR}$ [1]. Klein, Sunahara, Hudson, Heyduk and Howlett [13] reported decreased concentrations of cAMP in N18TG2 Neurblastoma cells

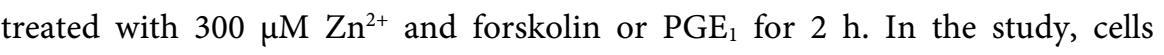
treated only with $\mathrm{Zn}^{2+}$, resulted in no effect on cAMP concentration [13]. Swaminath, Steenhuis, Kobilka and Lee [9] reported $\mathrm{Zn}$ binds to the $\beta 2 \mathrm{AR}$, causing increased agonist affinity and a greater production of cAMP. Swaminath, Lee and Kobilka [10] further reported multiple binding sites on the $\beta 2 \mathrm{AR}$ for $\mathrm{Zn}$, with the most prominent binding site for $\mathrm{Zn}$ causing an increase in agonist binding affinity and a decrease in antagonist affinity.

Relative mRNA abundance of $\beta 1 \mathrm{AR}, \beta 2 \mathrm{AR}, \mathrm{AMPK} \alpha$, IGF-1, MHC-I, MHC-IIA, MHC-IIX, GPR43, SCD, CEBP $\beta$, and PPAR $\gamma$ yielded no difference between treatments at $24 \mathrm{~h}(P>0.05$; Table 3$)$. At $96 \mathrm{~h}, \mathrm{ZH}$ cells tended to increase the abundance of MHC-I mRNA $(P<0.10$; Table 3$)$ compared to CON. Furthermore, $\mathrm{ZH}$ cells had a greater abundance of MHC-IIX mRNA $(P<0.05$; Table 3$)$ and a tendency for greater abundance of IGF-I mRNA $(P<0.15$; Table 3$)$ compared to $\mathrm{CON}$ and $\mathrm{Zn} / \mathrm{ZH}$. Harris [16] reported no differences in $\beta 1 \mathrm{AR}, \beta 2 \mathrm{AR}$, AMPK $\alpha$, IGF-1, MHC-I, MHC-IIA, MHC-IIX mRNA abundance of bovine cells treated with $\mathrm{Zn}$ and $\mathrm{RH}$ at 24 and $96 \mathrm{~h}$. Miller, Chung, Hutcheson, Yates, Smith and Johnson [2] however, reported a decrease in $\beta 1 \mathrm{AR}$ and $\beta 2 \mathrm{AR}$ mRNA abundance compared to control bovine cells, when cells were treated with $1 \mu \mathrm{M} \mathrm{ZH}$. Tokach [18] found bovine cells treated with $\mathrm{ZH}$ increased the abundance of IGF-I mRNA; however, ZH decreased MHC-I mRNA abundance and increased MHC-IIX mRNA abundance compared to control cells at $120 \mathrm{~h}$. In the current study, $\mathrm{ZH}$ increased the abundance of MHC-IIX mRNA $(P<0.05)$ and tended $(P<0.15)$ to increase the abundance of MHC-I mRNA compared to control cells at $96 \mathrm{~h}$.

Protein abundance of $\beta 1 \mathrm{AR}$ and $\beta 2 \mathrm{AR}$ showed no difference between treatments at either 24 or $96 \mathrm{~h}(P>0.05$; Table 4$)$. Our data support that of [16], who reported no change in $\beta 1 \mathrm{AR}$ and $\beta 2 \mathrm{AR}$ protein abundance of bovine cells treated with $\mathrm{Zn}$ and $\mathrm{RH}$ for 24 and 96 h. Miller, Chung, Hutcheson, Yates, Smith and Johnson [2] reported a decrease in $\beta 2 \mathrm{AR}$ protein when bovine cells were treated with varying levels of $\mathrm{ZH}$ compared to control cells.

Just as $\mathrm{Zn}$ and $\mathrm{ZH}$ affected protein expression in the cells, the combination also affected product signal transduction events downstream of binding. The increased binding affinity of $\mathrm{ZH}$ to the $\beta 2 \mathrm{AR}$ resulting from binding of $\mathrm{Zn}$ may 
Table 3. Relative alterations of mRNA concentrations of AMPK $\alpha$, IGF-I, MHC-I, MHC-IIA, MHC-IIX, $\beta 1 \mathrm{AR}, \beta 2 \mathrm{AR}, \mathrm{GPR} 43, \mathrm{SCD}, \mathrm{CEBP} \beta$, and PPAR $\gamma$ genes in bovine skeletal muscle satellite cells treated with zinc $(\mathrm{Zn})$ and zilpaterol hydrochloride $(\mathrm{ZH})$.

\begin{tabular}{|c|c|c|c|c|c|c|}
\hline \multicolumn{7}{|c|}{ Treatment $^{2}$} \\
\hline Gene $^{* 1}$ & Control & $\mathrm{ZH}$ & $\mathrm{Zn}$ & $\mathrm{Zn} / \mathrm{ZH}$ & $\mathrm{SEM}^{3}$ & $P$-Value \\
\hline \multicolumn{7}{|l|}{24 Hour } \\
\hline $\mathrm{AMPk} \alpha$ & 0.792 & 0.819 & 1.134 & 0.862 & 0.206 & 0.328 \\
\hline IGF-I & 2.394 & 18.566 & 5.474 & 10.172 & 8.642 & 0.339 \\
\hline MHC-I & 34.292 & 40.735 & 46.494 & 43.229 & 36.289 & 0.843 \\
\hline MHC-IIA & 92.801 & 208.030 & 81.721 & 59.259 & 84.236 & 0.458 \\
\hline MHC-IIX & 39.623 & 76.555 & 31.411 & 36.516 & 55.969 & 0.676 \\
\hline$\beta 1 \mathrm{AR}$ & 0.431 & 1.014 & 0.808 & 0.497 & 0.557 & 0.681 \\
\hline$\beta 2 \mathrm{AR}$ & 0.611 & 0.342 & 0.613 & 0.583 & 0.219 & 0.550 \\
\hline GPR43 & 0.037 & 4.179 & 0.836 & 0.455 & 2.300 & 0.168 \\
\hline SCD & 1.921 & 1.830 & 2.366 & 1.869 & 1.122 & 0.789 \\
\hline СЕВР $\beta$ & 1.051 & 1.421 & 1.528 & 1.836 & 0.648 & 0.944 \\
\hline $\operatorname{PPAR} \gamma$ & 0.133 & 1.699 & 0.403 & 0.393 & 0.760 & 0.148 \\
\hline \multicolumn{7}{|l|}{96 Hour } \\
\hline $\mathrm{AMPk} \alpha$ & 1.074 & 1.232 & 1.522 & 1.120 & 0.621 & 0.511 \\
\hline IGF-I & 54.439 & 89.368 & 73.977 & 59.397 & 16.307 & 0.053 \\
\hline MHC-I & 54.265 & 106.870 & 74.478 & 58.965 & 23.594 & 0.054 \\
\hline MHC-IIA & 62.873 & 115.700 & 75.909 & 26.646 & 93.129 & 0.403 \\
\hline MHC-IIX & $31.955 \mathrm{~b}$ & $90.481 \mathrm{a}$ & $52.485 \mathrm{ab}$ & $17.720 \mathrm{~b}$ & 18.407 & 0.003 \\
\hline$\beta 1 \mathrm{AR}$ & 0.372 & 0.375 & 0.888 & 0.819 & 0.715 & 0.941 \\
\hline$\beta 2 \mathrm{AR}$ & 0.295 & 0.253 & 0.418 & 0.331 & 0.216 & 0.876 \\
\hline GPR43 & 0.906 & 2.522 & 3.351 & 5.837 & 2.731 & 0.814 \\
\hline SCD & 2.579 & 3.239 & 1.841 & 2.154 & 2.347 & 0.913 \\
\hline СЕВР $\beta$ & 1.626 & 1.523 & 1.529 & 2.235 & 1.108 & 0.593 \\
\hline $\operatorname{PPAR} \gamma$ & 0.454 & 0.993 & 1.166 & 1.435 & 0.636 & 0.755 \\
\hline
\end{tabular}

a,bMeans in the same row having different superscripts are significant at $P=0.05 .{ }^{*} \mathrm{AMPK} \alpha=$ AMP-activated protein kinase alpha, IGF-1 = insulin like growth factor-1, MHC-I = myosin heavy chain-I, MHC-IIA = myosin heavy chain-IIA, MHC-IIX = myosin heavy chain-IIX, $\beta 1 \mathrm{AR}=$ beta 1 adrenergic receptor, $\beta 2 \mathrm{AR}=$ beta 2 adrenergic receptor, GPR43 = G-protein coupled receptor $43, \mathrm{SCD}=$ stearoyl-CoA desaturase, $\mathrm{CEBP} \beta=\mathrm{C}$-enhancer binding protein beta and $\operatorname{PPAR} \gamma=$ peroxisome proliferator-activated receptor gamma. ${ }^{1}$ Relative abundance of the AMPK $\alpha$, MHC-I, MHC-IIA, MHC-IIX, $\beta 1$ AR, $\beta 2$ AR, GPR43, SCD, CEBP $\beta$, and $\operatorname{PPAR} \gamma$ genes were normalized with the RPS9 endogenous control by using the change in cycle threshold $(\Delta \mathrm{CT}) .{ }^{2} \mathrm{Control}=0 \mu \mathrm{M} \mathrm{ZH} / 0 \mu \mathrm{M} \mathrm{Zn}$ chloride, $\mathrm{ZH}=10 \mu \mathrm{M} \mathrm{ZH/0} \mu \mathrm{M} \mathrm{Zn}$ chloride, $\mathrm{Zn}=0 \mu \mathrm{M} \mathrm{ZH} / 1$ $\mu \mathrm{M} \mathrm{Zn}$ chloride, $\mathrm{Zn} / \mathrm{ZH}=1 \mu \mathrm{M} \mathrm{Zn}$ chloride $/ 10 \mu \mathrm{M} \mathrm{ZH} .{ }^{3}$ Pooled standard error of the mean.

consequently result in an inhibition of the synthesis of cAMP. The cAMP data

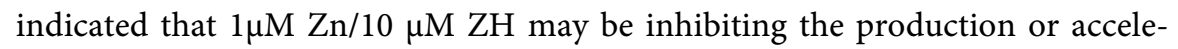
rating the degradation of cAMP. Lynch, Patson, Goodman, Trapolsi and Kimball [19] reported that $\mathrm{Zn}$ became inhibitory to cell growth at concentrations over 
Table 4. Relative protein concentration changes of beta $a_{1}$ and beta $a_{2}$-adrenergic receptors $(\beta \mathrm{AR})$ in bovine skeletal muscle satellite cells treated with zinc $(\mathrm{Zn})$ and zilpaterol hydrochloride $(\mathrm{ZH})$.

\begin{tabular}{ccccccc}
\hline \multicolumn{7}{c}{ Treatment $^{1}$} \\
\hline & Control & $\mathrm{ZH}$ & $\mathrm{Zn}$ & $\mathrm{Zn} / \mathrm{ZH}$ & $\mathrm{SEM}^{2}$ & $P$-Value \\
\hline 24 Hour & & & & & \\
$\beta 1 \mathrm{AR}^{3}$ & 22,521 & 22,256 & 21,880 & 21,575 & 2266 & 0.976 \\
$\beta 2 \mathrm{AR}^{3}$ & 27,676 & 27,173 & 26,441 & 26,462 & 2741 & 0.961 \\
96 Hour & & & & & & \\
$\beta 1 \mathrm{AR}^{3}$ & 21,120 & 20,173 & 20,942 & 21,012 & 2582 & 0.980 \\
$\beta 2 \mathrm{AR}^{3}$ & 26,203 & 25,588 & 25,514 & 29,001 & 3672 & 0.760 \\
\hline
\end{tabular}

${ }^{1}$ Control $=0 \mu \mathrm{M} \mathrm{ZH} / 0 \mu \mathrm{M}$ Zn chloride, $\mathrm{ZH}=10 \mu \mathrm{M} \mathrm{ZH} / 0 \mu \mathrm{M} \mathrm{Zn}$ chloride, $\mathrm{Zn}=0 \mu \mathrm{M} \mathrm{ZH} / 1 \mu \mathrm{M}$ Zn chloride, $\mathrm{Zn} / \mathrm{ZH}=1 \mu \mathrm{M} \mathrm{Zn}$ chloride $/ 10 \mu \mathrm{M} \mathrm{ZH} .{ }^{2}$ Pooled standard error of the mean. ${ }^{3}$ The values shown are the ratio of relative light units per second based on the intensity of the sample's protein band.

$100 \mu \mathrm{M}$. When $\beta$-AAs bind to a $\beta$-AR, intrinsic $\mathrm{Zn}$ is released. With $\mathrm{ZH}$ having a high affinity to bind to $\beta 2 \mathrm{ARs}$, which is the predominant $\beta$-AR found in beef cattle muscle and adipose tissue, and the $\beta 2 \mathrm{AR}$ potentially having multiple allosteric binding sites for $\mathrm{Zn}$ [9], the cell may be flooded with $\mathrm{Zn}$ from intrinsic and free sources of $\mathrm{Zn}$. This may in part cause $\mathrm{Zn}$ to become inhibitory towards AC thus reducing the amount of cAMP produced. Since cAMP is a secondary messenger in the $\beta$-AR pathway that leads to an increase in myogenic mRNA transcription and ultimately muscle protein accretion, this could possibly explain the decreased myogenic activity we observed. However, large concentrations of $\mathrm{Zn}$ increase the uptake of glucose and de novo lipogenesis [19], possibly partially elucidating the reason for increased adipogenic activity observed in this study.

Based on the results of this study, we can conclude that independently, $\mathrm{Zn}$ and $\mathrm{ZH}$ positively impact myogenic synthesis; however, cAMP production, $\beta$-AR protein and mRNA abundance may not be affected by the combination of the two compounds. Increasing $\mathrm{Zn}$ supplementation may increase the concentration of extracellular free $\mathrm{Zn}$; possibly increasing the binding affinity of the $\beta$-AA, therefore amplifying the signal transduction associated with $\beta$-AA. This amplified affect may result in over stimulation of the $\beta$-AR, thereby activating AC causing an increased release of intracellular $\mathrm{Zn}$, which could negatively impact cAMP. While there is conflicting evidence on the implications between the interactions of $\mathrm{Zn}, \beta$-AA and $\beta$-AR, these mechanisms are not fully understood, and future research should be conducted to further elucidate the molecular mechanisms that impact cellular muscle metabolism in biological processes involving $\mathrm{Zn}$. Caution should be used extrapolating these in vitro results to expected results of feeding $\mathrm{ZH}$ to beef cattle.

\section{Supported}

Supported in part by funding from Zinpro Corporation, Eden Prairie, Minneso- 
ta, and the Gordon W. Davis Regent's Chair in Meat and Muscle Biology Endowment at Texas Tech University, Lubbock.

\section{Conflicts of Interest}

The authors declare no conflicts of interest regarding the publication of this paper.

\section{References}

[1] Mersmann, H.J. (1998) Overview of the Effects of Beta-Adrenergic Receptor Agonists on Animal Growth Including Mechanisms of Action. Journal of Animal Science, 76, 160-172. https://doi.org/10.2527/1998.761160x

[2] Miller, E.K., Chung, K.Y., Hutcheson, J.P., Yates, D.A., Smith, S.B. and Johnson, B.J. (2012) Zilpaterol Hydrochloride Alters Abundance of $\beta$-Adrenergic Receptors in Bovine Muscle Cells But Has Little Effect on de Novo Fatty Acid Biosynthesis in Bovine Subcutaneous Adipose Tissue Explants. Journal of Animal Science, 90, 1317-1327. https://doi.org/10.2527/jas.2011-4589

[3] Tokach, R.J., Ribeiro, F.R.B., Chung, K.Y., Rounds, W. and Johnson, B.J. (2015) Chromium Propionate Enhances Adipogenic Differentiation of Bovine Intramuscular Adipocytes. Frontiers in Veterinary Science, 2, 26. https://doi.org/10.3389/fvets.2015.00026

[4] Abney, C.S., Vasconcelos, J.T., McMeniman, J.P., Keyser, S.A., Wilson, K.R., Vogel, G.J. and Galyean, M.L. (2007) Effects of Ractopamine Hydrochloride on Performance, Rate and Variation in Feed Intake, and Acid-Base Balance in Feedlot Cattle. Journal of Animal Science, 85, 3090-3098. https://doi.org/10.2527/jas.2007-0263

[5] Avendaño-Reyes, L., Torres-Rodríguez, V., Meraz-Murillo, F.J., Pérez-Linares, C., Figueroa-Saavedra, F. and Robinson, P.H. (2006) Effects of Two Beta-Adrenergic Agonists on Finishing Performance, Carcass Characteristics, and Meat Quality of Feedlot Steers. Journal of Animal Science, 84, 3259-3265.

https://doi.org/10.2527/jas.2006-173

[6] Lohse, M.J., Benovic, J.L., Caron, M.G. and Lefkowitz, R.J. (1990) Multiple Pathways of Rapid Beta 2-Adrenergic Receptor Desensitization. Delineation with Specific Inhibitors. Journal of Biological Chemistry, 265, 3202-3211.

[7] Waldo, G.L., Northup, J.K., Perkins, J.P. and Harden, T.K. (1983) Characterization of an Altered Membrane Form of the Beta-Adrenergic Receptor Produced during Agonist-Induced Desensitization. Journal of Biological Chemistry, 258, 13900-13908.

[8] Pippig, S., Andexinger, S., Daniel, K., Puzicha, M., Caron, M.G., Lefkowitz, R.J. and Lohse, M.J. (1993) Overexpression of Beta-Arrestin and Beta-Adrenergic Receptor Kinase Augment Desensitization of Beta 2-Adrenergic Receptors. Journal of Biological Chemistry, 268, 3201-3208.

[9] Swaminath, G., Steenhuis, J., Kobilka, B. and Lee, T.W. (2002) Allosteric Modulation of beta2-Adrenergic Receptor by $\mathrm{Zn}(2+)$. Molecular Pharmacology, 61, 65-72. https://doi.org/10.1124/mol.61.1.65

[10] Swaminath, G., Lee, T.W. and Kobilka, B. (2003) Identification of an Allosteric Binding Site for $\mathrm{Zn}^{2+}$ on the beta2 Adrenergic Receptor. Journal of Biological Chemistry, 278, 352-356. https://doi.org/10.1074/jbc.M206424200

[11] Hasse, H. and Rink, L. (2011) Zinc Signaling. In: Rink, L., Ed., Zinc in Human Health, IOS Press, Amsterdam, 94-117. 
[12] Brown, K.H., Peerson, J.M., Rivera, J. and Allen, L.H. (2002) Effect of Supplemental Zinc on the Growth and Serum Zinc Concentrations of Prepubertal Children: A Meta-Analysis of Randomized Controlled Trials. The American Journal of Clinical Nutrition, 75, 1062-1071. https://doi.org/10.1093/ajcn/75.6.1062

[13] Klein, C., Sunahara, R.K., Hudson, T.Y., Heyduk, T. and Howlett, A.C. (2002) Zinc Inhibition of cAMP Signaling. Journal of Biological Chemistry, 277, 11859-11865. https://doi.org/10.1074/jbc.M108808200

[14] Klein, C., Heyduk, T. and Sunahara, R.K. (2004) Zinc Inhibition of Adenylyl Cyclase Correlates with Conformational Changes in the Enzyme. Cell Signal, 16, 1177-1185. https://doi.org/10.1016/j.cellsig.2004.03.008

[15] von Bülow, V., Rink, L. and Haase, H. (2005) Zinc-Mediated Inhibition of Cyclic Nucleotide Phosphodiesterase Activity and Expression Suppresses TNF-Alpha and IL-1 Beta Production in Monocytes by Elevation of Guanosine 3',5'-Cyclic Monophosphate. Journal of Immunology, 175, 4697-4705.

https://doi.org/10.4049/jimmunol.175.7.4697

[16] Harris, T. (2013) The Effect of Zinc on the $\beta$-Adrenergic Receptor in Bovine Satellite Cells and the Use of $\beta$-Agonists and Steroid Implants on Muscle Protein and mRNA Levels in Feedlot Cattle. Master Thesis, Texas Tech University, Lubbock.

[17] Apple, J.K., Rincker, P.J., McKeith, F.K., Carr, S.N., Armstrong, T.A. and Matzat, P.D. (2007) Meta-Analysis of the Ractopamine Response in Finishing Swine. The Professional Animal Scientist, 23, 179-196. https://doi.org/10.15232/S1080-7446(15)30964-5

[18] Tokach, R. (2011) The Effects of Zilpaterol Hydrochloride and Chromium Propionate on Bovine Muscle Satellite Cells and Preadipocytes. Master Thesis, Texas Tech University, Lubbock.

[19] Lynch, C.J., Patson, B.J., Goodman, S.A., Trapolsi, D. and Kimball, S.R. (2001) Zinc Stimulates the Activity of the Insulin- and Nutrient-Regulated Protein Kinase mTOR. American Journal of Physiology Endocrinology and Metabolism, 281, E25-E34. https://doi.org/10.1152/ajpendo.2001.281.1.E25 